\title{
OPTIMASI PERLAKUAN POLYETHYLENE GLIKOL (PEG) 6000 TERHADAP ISOLASI AGAROSA RUMPUT LAUT Glacilaria sp.
}

\author{
Siti Martinah ${ }^{1} *$, RTM. Sutamihardja ${ }^{1)}$, Lilis Sugiarti ${ }^{2)}$ \\ 1)*Program Studi Kimia FMIPA Universitas Nusa Bangsa Bogor \\ Jl. KH Soleh Iskandar KM 4 Cimanggu Tanah Sareal Bogor 16166 \\ ${ }^{2)}$ Program Studi DIII Farmasi STIKES Cendekia Utama Kudus \\ Jl. Lingkar Raya Kudus-Pati KM. 5 Jepang Kecamatan Mejobo Kabupaten Kudus \\ *e-mail : sitimartina49@yahoo.com
}

\author{
ABSTRACT \\ Optimation of Polyethylene Glycol (PEG) 6000 Treatment on Isolation of \\ Agarose Seaweeds of Glacilaria sp
}

\begin{abstract}
Isolation of agarose from seaweeds (Glacilaria sp) had been done in acid, base, and neutral condition by using polyethylene glycol (PEG) method. Glacilaria sp, Seaweeds that used in this research was cultured by farmer in Muara Gembong, Bekasi. It used PEG with concentration 10\%, 15\%, 20\%, 25\%, \& 30\%. The scope of this research ware determination of seaweeds, seaweeds water content, isolation of agarose from seaweeds, and quality test of agarose. Parameter test of agarose quality include the strength of gel, the content of sulfat, measurement of galactose content and its proksimat. The high yield was $61,27 \% \mathrm{r}$ in PEG $30 \%$. The best quality of agarose was resulted in PEG $20 \%$ because of the highest strength of gel was $379,04 \mathrm{~g} / \mathrm{cm}^{2}$. The lowest sulfat concentration was $1,33 \%$ and galactose was $17,39 \%$.
\end{abstract}

Key words: polyethylene glycol, PEG 6000, agarose, seaweeds, glacilaria sp

\begin{abstract}
ABSTRAK
Isolasi agarosa dari rumput laut Glacilaria $s p$ telah dilakukan dalam suasana asam, basa dan netral dengan metode polyethylene glikol (PEG). Rumput lauat yang digunakan adalah Gracilaria $s p$ yang dibudidayakan oleh petani di Muara Gembong, Bekasi dengan perlakuan konsentrasi PEG 10\%, 15\%, 20\%, 25\% dan 30\%. Ruang lingkup penelitian ini meliputi uji determinasi rumput laut, penetapan kadar air rumput laut, isolasi agarosa dari rumput laut, serta uji kualitas agarosa. Parameter pengujian kualitas agarosa terdiri dari kekuatan gel, kandungan sulfat, dan pengukuran kandungan galaktosa serta proksimatnya. Isolasi agarosa perlakuan konsentrasi polyethylene Glikol (PEG) 6000 pada rumput laut Glacilaria sp diperoleh rendemen paling tinggi terdapat pada perlakuan PEG $30 \%$ yaitu sebesar $61,27 \%$. Akan tetapi untuk kualitas agarosa yang paling baik terdapat pada perlakuan konsentrasi PEG 20\% karena diperoleh kekuatan gel paling tinggi sebesar 379,04 g/ $\mathrm{cm}^{2}$. Kadar sulfat yang paling rendah sebesar $1,33 \%$ dan kadar galaktosa sebesar 17,39\%.
\end{abstract}

Kata Kunci: polyethylene glikol, PEG 6000, agarosa, rumput laut, glacilaria $s p$

\section{PENDAHULUAN}

Agarosa dihasilkan melalui proses isolasi dari rumput laut jenis Agarofit yaitu Gracilaria dan Gelidium. Metabolit primer yang dikandung oleh kedua jenis rumput laut tersebut adalah agar. Agarosa memiliki muatan listrik mendekati netral, oleh karena itu, senyawa ini memiliki kemampuan membentuk gel yang kuat. (Fitri, 1992).

Agarosa dijual di pasaran dengan harga yang cukup mahal, harga jual agarosa dipasaran adalah 1000 - 5000 dollar Amerika per kilogram, hal ini disebabkan oleh fungsi- nya yang sangat penting dalam bidang kimia dan biologi (Subaryono et al., 2003). Para pengusaha lebih dominan untuk memproses rumput laut menjadi produk agar-agar makanan dibandingkan sebagai agarosa, karena prosesnya lebih murah dan mudah (Anggadireja et al., 2006). Agarosa yang diproduksi saat ini hanya diisolasi dari rumput laut jenis Gracilaria dan Gelidium. Metode pengambilan rumput laut ada beberapa macam, salah satunya metode praperlakuan asam sebelum ekstraksi (Munaf 2000 dalam Distianti et al. 2006). Berdasarkan percobaan Armeidy (1992) mengguna- 
kan asam asetat $\left(\mathrm{CH}_{3} \mathrm{COOH}\right) 1 \%$ pada bahan baku Gracilaria verrucosa, terbukti dapat meningkatkan rendemen dan kekuatan gel agar-agar yang dihasilkan. Percobaan Fitri (1992) proses isolasi menggunakan metode PEG terbukti dapat meningkatkan rendemen agarosa. Luas penyebaran rumput laut di Indonesia untuk marga Gracilaria mencapai $255 \mathrm{~km}^{2}$, Eucheuma $215 \mathrm{~km}^{2}$ dan Gelidium $47 \mathrm{~km}^{2}$. Oleh karena itu perlu dilakukan penelitian mengenai potensi rumput laut jenis Gracilaria dalam memproduksi agarosa (Rachmat et al., 2004).

Pemanfaatan rumput laut jenis Gracilaria dan Gelidium lebih dominan sebagai agar-agar karena prosesnya yang lebih mudah dengan biaya yang lebih murah. Agarosa yang diproduksi saat ini hanya diisolasi dari rumput laut jenis Gracilaria dan Gelidium. (Rachmat et al., 2004). Menurut Sijian dalam Fitri 1992. untuk mengisolasi agarosa dari rumput laut menyebutkan bahwa penggunaan PEG yang terbaik antara $5 \%-20 \%$. tetapi belum menyebutkan mengenai pemberian konsentrasi PEG 6000 yang optimum pada saat isolasi agarosa. Pada penelitian ini menggunakan perlakuan dengan konsentrasi PEG 10\%, $15 \%, 20 \%, 25 \%$ dan 30\% diharapkan bisa mendapatkan konsentrasi yang optimum dari PEG 6000 yang digunakan untuk isolasi agarosa rumput laut Gracilaria, sehingga rendemen agarosa yang dihasilkan banyak dan kualitasnya menjadi lebih baik.
Gracilaria sp. dibudidayakan oleh petani di Muara Gembong, Bekasi. Gracilaria sp. merupakan salah satu rumput laut penghasil agar-agar atau agarofit. Agarofit tersusun atas agarosa dan agaropektin. Agarosa adalah suatu fraksi penyusun agar-agar, merupakan senyawa agar yang telah dipisahkan dari unit molekul agaropektin dengan muatan listrik mendekati netral, agarosa umumnya bebas sulfat. Sedangkan agaropektin merupakan senyawa agar yang mengandung muatan sulfat. Rasio perbandingan antara agaropektin dan agarosa pada agar yaitu $50-90 \%$.

Untuk isolasi agarosa dari rumput laut Gracilaria sp dapat dilakukan dalam suasana asam, basa dan netral dengan metode polietilen glikol (PEG) tergantung jenis rumput laut yang digunakan (Chapman dan Chapman 1980 dalam Asmarita 2000). Ekstraksi pada $\mathrm{pH}$ netral hanya dilakukan untuk rumput laut yang diberikan praperlakuan asam (Armeidy, 1992). Fitri (1992) menggunakan PEG $10 \%$ untuk isolasi agarosa dari agar-agar Gracilaria sp dapat meningkatkan rendemen. Metode PEG didasarkan pada kelarutan agarosa yang tereduksi dalam media yang menggunakan polietilen glikol (Fransiska dan Murdinah, 2007). Mekanisme reaksi agarosa dan polietilen glikol (PEG) dapat dilihat pada Gambar 1.

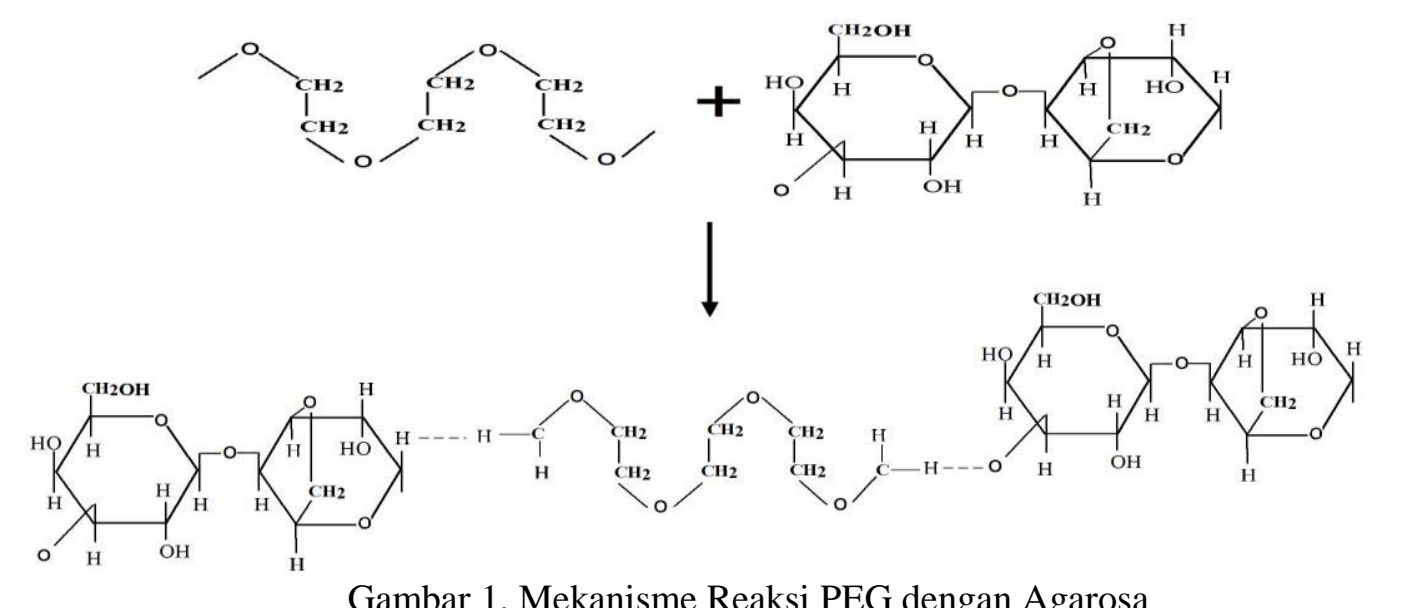

Gambar 1. Mekanisme Reaksi PEG dengan Agarosa 
Untuk meyakinkan bahwa hasil isolasi agarosa berkualitas baik, maka dilakukan pengujian rendemen (ekstrak) agarosa yang meliputi kekuatan gel, kandungan sulfat, dan pengukuran galaktosa serta proksimatnya (Rachmat et al., 2004). Semakin tinggi konsentrasi Polietilen Glikol (PEG) 6000 maka rendemen ekstrak agarosa semakin tinggi. Ada konsentrasi PEG 6000 yang optimum untuk mendapatkan kualitas agarosa terlihat dari kekuatan gel yang tinggi dan kadar sulfatnya yang rendah.

\section{BAHAN DAN METODA}

\section{Alat dan Bahan}

Alat-alat yang digunakan adalah neraca analitik, labu Kjehdahl, kertas whatman saring (Whatman 41), oven, tanur, corong Buchner, water bath, Texture Analyzer, sentrifuse, batang pengaduk, gelas piala, lemari es, filter 150 mesh, cawan porselen, spatula, esikator, soxhlet, stirrer, erlenmeyer, buret, batu didih, kertas lakmus, pipet tetes, pipet volumetrik, piper mohr, gelas ukur, pendingin tegak, labu ukur, hot plate, labu penyari.

Bahan-bahan yang digunakan adalah rumput laut jenis Gracilaria sp yang berasal dari Budidaya Rawa Gembong Bekasi, $\mathrm{CH}_{3} \mathrm{COOH}, \mathrm{CaO}, \mathrm{NaOH}, \mathrm{HCl}, \mathrm{K}_{2} \mathrm{SO}_{4}$, $\mathrm{NaCl}$, Polietilen Glikol (PEG) 6000, asam borat, indikator campuran (brom cresolgreen: metil merah), akuades, larutan Luff, Petroleum Eter, $\mathrm{BaCl}_{2}, \mathrm{KCl}, \mathrm{Na}-$ tiosulfat, $\mathrm{KIO}_{3}, \mathrm{KI}, \mathrm{H}_{2} \mathrm{SO}_{4}, \mathrm{H}_{2} \mathrm{O}_{2}, \mathrm{BaCl}_{2}$, larutan pati, aseton, dan Selenium.

\section{Isolasi Agarosa dari Rumput Laut Gracilaria}

Rumput laut kering yang telah bersih ditimbang sebanyak $30 \mathrm{~g}$, dipotong kasar direndam dan dicuci dengan menggunakan air bersih, kemudian dipucatkan dengan larutan $\mathrm{CaO} 1 \%$ selama 1 jam. Rumput laut lalu dicuci hingga $\mathrm{pH}$ netral dan dilanjutkan dengan tahapan praperlakuan asam. Pada praperlakuan asam, rumput laut dimasukkan ke dalam $\mathrm{CH}_{3} \mathrm{COOH} 2 \mathrm{~N}$ dengan perbandingan $1: 10$. Selama praperlakuan asam rumput laut dipanaskan pada suhu 60 ${ }^{\circ} \mathrm{C}$ selama 1 jam. Setelah proses praper- lakuan asam, rumput laut dicuci kembali dengan air hingga $\mathrm{pH}$ netral selajutnya dilakukan ekstraksi, rumput laut dimasukkan ke dalam air dengan perbandingan 1:20 dan dipanaskan pada suhu $85^{\circ} \mathrm{C}$ selama 2 jam. Rumput laut yang telah diekstraksi lalu disaring dengan menggunakan saringan kain berukuran 150 mesh. Filtrat hasil penyaringan ditambahkan perlakuan PEG 6000 sebanyak 10\%, 15\%, 20\%, 25\%, dan 30\% (b/v) dan $\mathrm{NaCl}$ sebanyak $1 \%$ (b/v) kemudian dipanaskan kembali selama 30 menit.

Setelah proses pemanasan selesai filtrat disaring kembali dengan kain penyaring berukuran 150 mesh. Filtrat dimasukkan ke dalam pan-pan pencetak dan didiamkan selama 24 jam pada suhu kamar, kemudian dikeringkan. Setelah kering lalu di grinder hingga menjadi tepung.

\section{Rendemen Agarosa}

Rendemen agarosa dihitung berdasarkan berat rumput laut bersih kering. Pengukuran dengan menimbang agarosa yang dihasilkan dibagi dengan berat rumput laut kering yang diekstraksi, sebagai berikut:

rendemen $(\%)=\frac{\text { berat agarosa } \text { kering }(g)}{\text { berat rumput laut }(g)} \times 100 \%$

\section{Uji Kualitas Agarosa \\ a. Pengukuran Kekuatan Gel ( $\mathrm{Gel}$ Strength)}

Sebanyak 1 gram sampel agarosa ditambahkan $0.18 \mathrm{~g} \mathrm{KCl}$ dan $80 \mathrm{~mL}$ akuades dalam gelas piala, lalu dipanaskan sampai suhu $80{ }^{\circ} \mathrm{C}$ sambil terus diaduk. Larutan panas kemudian dituangkan ke dalam cawan untuk dipadatkan dan disimpan pada suhu $20{ }^{\circ} \mathrm{C}$ selama 1 jam. Kekuatan gel diukur menggunakan Stevens LRFA Texture Analyzer.

kekuatan gel $=\frac{p p s \times p p k \times b k}{d s p g} \times 100 \%$

Keteragan :

Pps = penjang peak sample

Ppk = panjang peak kalibrasi

$\mathrm{Bk}=$ bobot kalibrasi

Dspg $=$ diameter silinder penekan gel 


\section{b. Pengukuran Kadar Sulfat (Pusat Penelitian dan Pengembangan \\ Perikanan, 1991)}

Sampel agar-agar sebanyak $1 \mathrm{~g}$ dimasukkan dalam erlenmeyer dan ditambahkan $50 \mathrm{~mL} \mathrm{HCl} \mathrm{0,2} \mathrm{N.} \mathrm{Erlenmeyer} \mathrm{dipasang}$ pada penangas tegak dan dipanaskan sampai mendidih, kemudian direfluks selama 1 jam. Larutan ditambahkan dengan $25 \mathrm{~mL} \mathrm{H}_{2} \mathrm{O}_{2}$ $10 \%$ dan refluks kembali selama 5 jam. Larutan kemudian dipindahkan ke dalam gelas piala $600 \mathrm{~mL}$, dipanaskan sampai mendidih sambil diaduk lalu ditambahkan $10 \mathrm{~mL} \mathrm{BaCl}_{2} 10 \%$ setetes demi setetes selama 2 jam. Endapan yang terbentuk kemudian disaring menggunkan kertas Whatman 41, lalu dicuci dengan akuadest mendidih sampai bebas klorida. Kertas saring dikeringkan dalam oven kemudian diabukan pada suhu $800{ }^{\circ} \mathrm{C}$ dalam tanur sampai didapatkan abu yang berwarna putih. Abu yang diperoleh didinginkan dalam eksikator dan ditimbang.

kadar sulfat $=\frac{\text { bobot abu }(g) \times 0,4116}{\text { bobot sampel }(g)} \times 100 \%$

\section{c. Pengukuran karbohidrat (galaktosa)}

Sampel agarosa sebanyak 1 gram dimasukkan ke dalam Erlenmeyer $500 \mathrm{ml}$, tambahkan $200 \mathrm{ml}$ asam klorida $3 \%$. Campuran tersebut kemudian dipanaskan dengan pendingin tegak selama 3 jam, selanjutnya didinginkan dan dinetralkan dengan $13 \mathrm{ml}$ natrium hidroksida $50 \%$. Larutan kemudian dibuat agak asam, diencerkan dengan $250 \mathrm{ml}$ akuadest dan disaring.

Sebanyak $10 \mathrm{ml}$ larutan contoh dimasukkan ke dalam Erlenmeyer $250 \mathrm{ml}$ dan ditambahkan larutan luff dan 25 akuadest. Kemudian didihkan 10 menit dan didinginkan dengan es. Ke dalam larutan ditambahkan $10 \mathrm{ml}$ larutan kalium iodida $30 \%$ dan $25 \mathrm{ml}$ larutan asam sulfat $25 \%$. Terakhir dititrasi dengan natrium tiosufat 0,1 $\mathrm{N}$ dengan indikator amilum $0,5 \%$.

Dengan cara yang sama lakukan blanko. Selisih volume natrium tiosulfat untuk blanko dan contoh dikonversi menjadi bobot galaktosa dalam tabel luff schoorl. Bandingkan dengan standar agarosa dan lakukan pengukuran kandungan galaktosa ini sebanyak 2 kali pengulangan.

Kandungan galaktosa $=$

Bobot galaktosa $\mathrm{xp} \times 100 \%$

Bobot contoh

\section{Analisis Proksimat \\ a. Penentuan Kadar Air (AOAC, 2000).}

Cawan porselin kosong dikeringkan pada suhu $105^{\circ} \mathrm{C}$ selama 1 jam. Kemudian didinginkan dalam eksikator lalu ditimbang. Sampel sebanyak $2 \mathrm{~g}$ dimasukkan ke dalam cawan, ditimbang dan dicatat, kemudian cawan berisi sampel dimasukkan ke dalam oven pada suhu $105{ }^{\circ} \mathrm{C}$ selama 1 jam lalu didinginkan, dimasukkan dalam eksikator selama 15 menit dan ditimbang dengan teliti dan dicatat hingga mencapai bobot yang konstan.. Kadar air dihitung.

kadar air $(\%)=\frac{\text { kehilangan bobot }(g)}{\text { bobot contoh }(g)} \times 100 \%$

\section{b. Penentuan Kadar Abu (AOAC, 2000).}

Cawan porselen yang telah bebas dari kotoran dan lemak ditimbang, dan dicatat. Sampel sebanyak $2 \mathrm{~g}$ dimasukkan dalam cawan, ditimbang dan dicatat. Lalu dipanaskan dengan pembakar bunsen sampai tidak berasap lagi. Cawan yang berisi sampel tadi kemudian dimasukkan ke dalam tanur dengan suhu $600{ }^{\circ} \mathrm{C}$, selama 5 jam. Lalu didinginkan dalam eksikator selama 30 menit, kemudian ditimbang dan dicatat hingga mencapai bobot yang konstan.

kadar abu $(\%)=\frac{\text { berat abu }(g)}{\text { berat contoh }(g)} \times 100 \%$

\section{c. Penentuan Kadar Lemak Kasar (AOAC, 2000).}

Labu lemak dengan beberapa batu didih dikeringkan dalam oven pada suhu $105^{\circ} \mathrm{C}$ selama 1 jam. Kemudian didinginkan dalam eksikator dan ditimbang. Kertas saring bebas lemak, dibuat selongsong lalu ditimbang dan dicatat. Sampel sebanyak 2 g dimasukkan dalam selongsong dan ditimbang. Selongsong yang berisi sampel dimasukkan ke dalam alat soxhlet dan diberi pelarut Petroleum Eter sebanyak $150 \mathrm{~mL}$ ke dalam labu lemak, lalu diekstraksi. Ekstraksi 
dilakukan selama 4 jam. Setelah diekstraksi, labu dikeringkan dalam oven pada $105{ }^{\circ} \mathrm{C}$ selama 1 jam. Kemudian didinginkan dalam eksikator selama 15 menit lalu ditimbang dan dicatat. Kadar lemak kasar dihitung.

$$
\text { kadar lemak }(\%)=\frac{\text { bobot lemak }(g)}{\text { bobot contoh }(g)} \times 100 \%
$$

\section{d. Penentuan Kadar Protein Kasar (SNI, 1998).}

Sampel ditimbang dengan teliti sebanyak 0,1 gram, dimasukkan ke dalam labu Kjeldahl, ditambahkan 0,65 gram campuran Selenium dan 2,5 $\mathrm{mL} \mathrm{H}_{2} \mathrm{SO}_{4}$ pekat. Semua bahan dalam labu dipanaskan dalam lemari asam sampai cairan berhenti berasap. Setelah tidak berasap, pemanasan diteruskan dengan api besar sampai mendidih dan larutan menjadi jernih. Lalu didinginkan. Larutan diencerkan dengan menambahkan akuades sebanyak $10 \mathrm{~mL}$ kemudian larutan dipindahkan ke dalam alat destilasi dan dibilas dua atau tiga kali dengan $3 \mathrm{~mL}$ akuades, lalu di tambahkan $10 \mathrm{~mL} \mathrm{NaOH}$ $67 \%$. Uap air dialirkan melewati alat destilasi dan destilat ditampung ke dalam erlenmeyer yang berisi $10 \mathrm{~mL}$ asam borat dan 2-3 tetes indikator BCG/MM (1:1) atau Mengsel., waktu destilasi ditentukan selama 5 menit (stopwatch). Erlenmeyer yang berisi hasil sulingan dititar dengan $\mathrm{H}_{2} \mathrm{SO}_{4} 0,01 \mathrm{~N}$ kemudian dicatat sebagai volume contoh.

protein $(\%)=\frac{(N \times V) H 2 S O 4 \times 14.007 \times 6.25(g)}{\text { berat contoh }(g) \times 1000} \times 100 \%$

e. Penentuan Kadar Serat (AOAC, 2000).

Sebanyak $1 \mathrm{~g}$ sampel didestruksi dalam $500 \mathrm{~mL} \mathrm{H}_{2} \mathrm{SO}_{4} 0,3 \mathrm{~N}$ selama 30 menit dan ditambahkan $25 \mathrm{~mL} \mathrm{NaOH} \mathrm{1,5} \mathrm{N,} \mathrm{kemudian}$ dididihkan kembali selama 30 menit. Filtrat disaring melalui kertas saring Whatman 41 yang telah dikeringkan dalam oven pada suhu 105-110 ${ }^{\circ} \mathrm{C}$, selama 1 jam. Hasil saringan dicuci dengan $50 \mathrm{ml}$ akuades panas, $50 \mathrm{~mL} \mathrm{H}_{2} \mathrm{SO}_{4} 0,3 \mathrm{~N}, 50 \mathrm{~mL}$ akuades panas dan $50 \mathrm{~mL}$ aseton. Kertas saring dan isinya dimasukkan ke dalam cawan porselin yang telah dikeringkan dalam oven pada suhu $105-110{ }^{\circ} \mathrm{C}$ selama $1 \mathrm{jam}$. Setelah itu cawan diabukan dalam tanur pada suhu $600{ }^{\circ} \mathrm{C}$ selama 1 jam, didinginkan dalam eksikator, ditimbang dan dicatat.

kadar Serat Kasar $=\frac{B R-B A}{B S} \times 100 \%$

Keterangan:

$\mathrm{BR}=$ Bobot Residu (g)

$\mathrm{BA}=$ Bobot Abu (g)

$\mathrm{BS}=$ Bobot Sample $(\mathrm{g})$

\section{HASIL DAN PEMBAHASAN}

\section{Proses Pemisahan Agarosa dari Rumput Laut Kering Gracilaria sp. \\ a. Proses Pra Ekstraksi}

Proses pra ekstraksi rumput laut Gracilaria sp. yang dihasilkan pada penelitian ini berupa rumput laut yang berwarna kuning kecoklatan sedikit lunak dengan $\mathrm{pH}$ netral. Proses pemisahan agarosa dari rumput laut kering Gracilaria $s p$. dilakukan dengan beberapa tahap yaitu pertama, pemucatan dengan Kalium Oksida $(\mathrm{CaO})$, kedua penetralan, ketiga praperlakuan asam, dan yang terakhir penetralan kembali. Pemucatan dilakuan dimana rumput laut sebelum ditambahkan $\mathrm{CaO}$ berwarna ungu kemerah-merah tetapi setelah direndam dalam larutan $\mathrm{CaO}$ menjadi berwarna kuning kecoklatan. Kalium Oksida digunakan sebagai pemucat karena mempunyai beberapa kelebihan diantaranya mudah diperoleh, harganya relatif murah, baunya tidak menyengat serta waktu yang diperlukan untuk pemucatan cukup singkat (Tanikawa 1985). Pada dasarnya pemucatan dengan $\mathrm{CaO}$ adalah dengan mendegradasi klorofil dan karoten secara oksidasi (Armeidy, 1992). Menurut Eskin et al dalam Armeidy, 1992. mengemukakan bahwa oksigen dapat mendegradasi klorofil menjadi senyawa yang tidak berwarna yang disebut klorin dan purpurin.

Tahap kedua yaitu penghilangan unsurunsur alkali dengan cara pencucian. Tahap ketiga proses praperlakuan asam dengan menggunkan Asam Asetat Glasial $\left(\mathrm{CH}_{3} \mathrm{COOH}\right) 2 \mathrm{~N}$ pada proses ini, Rumput Laut yang awalnya berupa lembaran keras setelah praperlakuan asam bentuknya menjadi lunak dan filtratnya sedikit mengental . Menurut Matsuhashi (1977), keuntungan 
perlakuan asam dibandingkan dengan alkali adalah dapat memperpendek waktu ekstraksi dan meningkatkan rendemen agar-agar. Proses perendaman dengan asam bertujuan untuk memecah dinding-dinding sel, sehingga agar-agar menjadi lebih mudah diekstrak. Kemudian pencucian kembali dengan air hingga $\mathrm{pH}$ netral.

\section{b. Ekstraksi}

Hasil ekstraksi rumput laut menjadi agarosa pada penelitian ini dihasilkan serbuk ekstrak agarosa berbentuk serbuk padatan yang dihaluskan menggunakan blender, serbuk agarosa berwarna kuning kecoklatan, sedangkan agar-agar komersil (Swallow) berwarna putih tulang. Perbedaan warna ini kemungkinan disebabkan oleh zat pemucat yaitu larutan $\mathrm{CaO} 1 \%$ belum maksimal saat perendaman sehingga pigmen warna dari rumput laut Gracilaria masih melekat . Adapun perbedaan serbuk agarosa hasil ekstraksi dengan standar agar-agar komersil dapat dilihat pada Gambar 2.

Pada Gambar 2a, 6b dan 6c di atas terlihat bahwa serbuk agarosa yang dihasilkan berturut-turut dari perlakuan PEG $10 \%, 15 \%, 20 \%, 25 \%$ dan $30 \%$ memiliki warna yang relatife sama yaitu berwarna kuning kecoklatan, dan serbuk yang dihasilkan juga berupa serbuk halus dengan ukuran butiran yang sama. Sehingga tidak ada perbedaan yang signifikan dikarenakan pada saat sebelum diekstraksi, Rumput Laut dipucatkan dengan larutan $\mathrm{CaO}$ pada konsentrasi yang sama yaitu dalam larutan $\mathrm{CaO} 1 \%$, untuk memperkecil luas permukaan rumput laut sebelum diekstraksi diblender terlebih dulu, diharapkan banyak agarosa yang terekstrak. Ekstraksi rumput laut dilakukan dengan cara ekstraksi pemanasan pada suhu $85^{\circ} \mathrm{C}$ selama 2 jam, menggunakan pelarut air aquadest dengan perbandingan 1:30 ml. Menurut Armeidy (1992), ekstraksi dapat dilakukan pada $\mathrm{pH}$ netral dan suhu $100^{\circ} \mathrm{C}$ karena proses ekstraksi akan lebih cepat yaitu selama $1-4$ jam. Pembuatan agarosa dari rumput laut berdasarkan pada prinsip bahwa agar-agar larut dalam air panas tetapi relatif tidak larut dalam air dingin, sehingga ekstraksi rumput laut dilakukan di dalam air panas (mendidih). Agar-agar mempunyai gugus hidrofilik ester sulfat yang rendah dan gugus hidrofobik 3,6-anhidro-L-galaktosa yang tinggi, sehingga agar-agar tidak larut dalam air dingin (Armeidy, 1992).

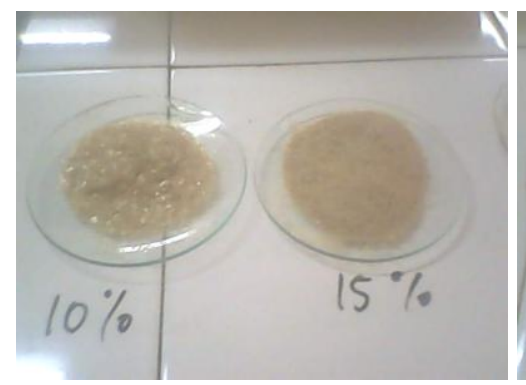

(a)

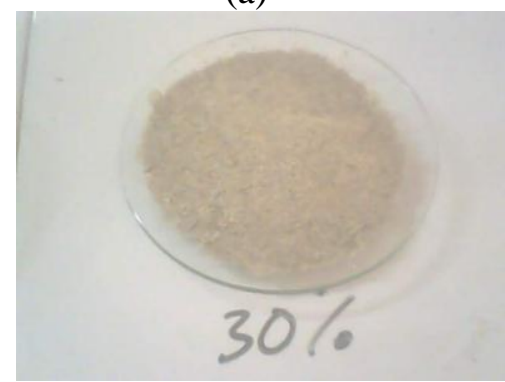

(c)

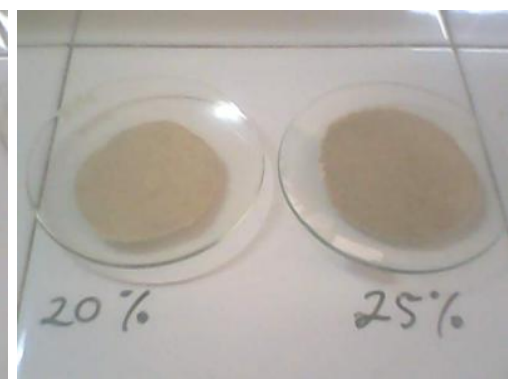

(b)

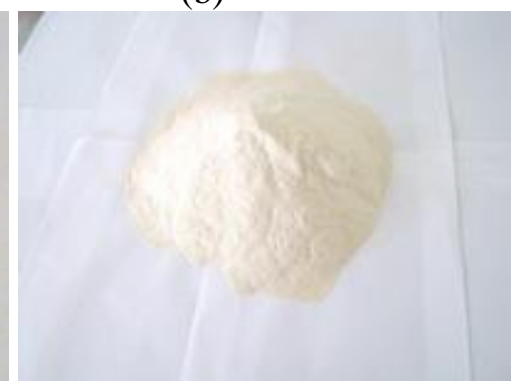

(d)

Gambar 2. a), b), dan c) Agarosa Hasil Eekstraksi dari Rumput Laut Gracilaria sp. d) Agar-agar Komersil (Swallow) 
Saat penambahan poliethyilen Glikol (PEG) 6000 dan Natrium Klorida $(\mathrm{NaCl})$. Larutan berwarna kuning kecoklatan berupa larutan koloid, dimana larutan ini lebih kental. PEG yang ditambahkan berfungsi untuk memisahkan agarosa dengan agaropektin, sedangkan penambahan Natrium Klorida untuk meningkatkan reaktifitas dari agaropektin sehingga kelarutannya meningkat. Dengan meningkatnya kelarutan menyebabkan perbedaan polaritas yang besar antara agarosa dan agaropektin. Agaropektin bersifat lebih polar sehingga akan larut sedangkan agarosa akan mengendap (Fitri, 1992).

Penyaringan dilakukan pada saat kondisi larutan masih panas, sedangkan agarosa larut pada suhu panas sehingga agarosa lolos dari saringan walaupun ada sedikit endapan namun diduga unsur kotoran yang berasal dari garam Natrium. Agarosa yang diperoleh dari penelitian ini bukan sebagai endapan tetapi berupa larutan yang kemungkinan masih bercampur dengan agaropektin karena pada saat penyaringan tidak memberikan waktu kepada agarosa untuk menjendal, sehingga larutan dapat tersaring semuanya. Pada dasarnya agarosa merupakan senyawa yang dapat membentuk gel dengan cepat di bawah suhu $60 \mathrm{oC}$. Agaragar yang telah kering dihaluskan dengan gringer membentuk seperti tepung agar-agar.

\section{c. Rendemen}

Nilai rendemen agar dihitung berdasarkan perbandingan berat agar yang diperoleh dari ekstraksi terhadap berat rumput laut kering. Rendemen agarosa yang dihasilkan pada penelitian ini berkisar antara 27,25 $61,27 \%$. Adapun hubungan antara rendemen rata-rata dengan perlakuan konsentrasi PEG 6000 dapat dilihat pada Gambar 7.

Berdasarkan Gambar 3 terlihat bahwa rendemen mengalami kenaikan pada setiap penambahan konsentrasi PEG. Nilai rendemen terendah yaitu $27,25 \%$ dari perlakuan PEG $10 \%$ dan rendemen tertinggi yaitu $61,22 \%$ dari perlakuan PEG 30\%. Hasil penelitian menunjukkan bahwa perlakuan konsentrasi PEG 6000 berbanding lurus terhadap rendemen agarosa yang dihasilkan. Semakin tinggi konsentrasi PEG maka rendemen yang dihasilkan semakin tinggi/besar, Hal ini berarti agarosa yang dihasilkan terekstrak lebih banyak. PEG juga merupakan suatu polimer dengan berat molekul yang besar sehingga semakin banyak PEG yang ditambahkan maka hasil rendemennya semakin tinggi.

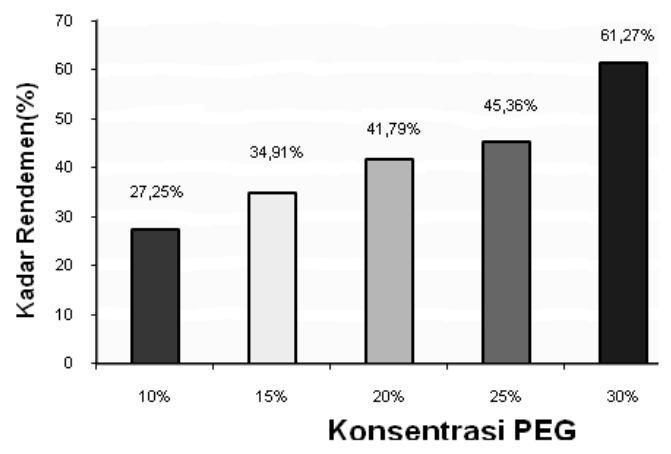

Gambar 3. Histogram Hubungan antara Nilai Rendemen dengan Konsentrasi PEG

Hasil ini lebih tingggi dari yang dilakukan oleh Chapman dan Chapman (1980) bahwa rendemen agar-agar dari ganggang merah jenis Gracilaria verrucosa adalah $25-35 \%$. Menurut Armeidy (1980), besarnya rendemen juga dipengaruhi oleh cara proses pengolahan yang dipilih. Faktor lain yang mempengaruhi hasil rendemen salah satu diantaranya, adalah cara ekstraksi agar-agar, yang hanya dilakukan satu kali sehingga diduga masih banyak agar-agar yang terdapat di dalam ampas Rumput Laut. Yang mempengaruhi besarnya rendemen menurut Chapman (1970) adalah keasaman $(\mathrm{pH})$ larutan ekstraksi yang diatur sekitar 6,5 dengan penambahan asam.

\section{d. Kualitas Agarosa \\ 1) Kekuatan Gel}

Kekuatan gel merupakan beban maksimum yang dibutuhkan untuk memecah matriks polimer pada daerah yang dibebani. Gel yang kuat merupakan kriteria yang penting sehubungan dengan penggunaan agarosa dalam bioteknologi.

Berdasarkan hasil penelitian, kekuatan gel berkisar antara 114,08-379.04 gr/cm2 Adapun hubungan antara kekuatan Gel dengan konsentrasi agarosa dapat dilihat pada Gambar 4. 


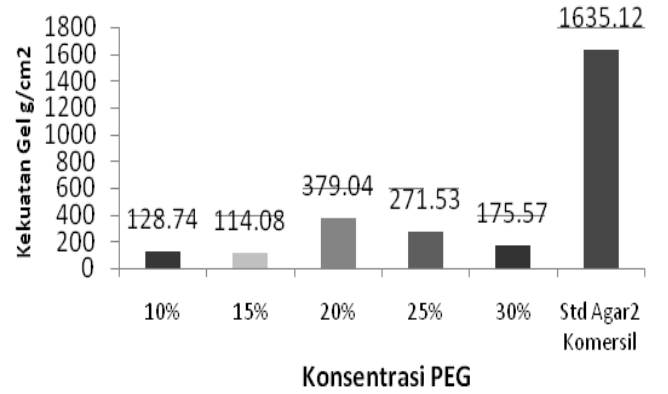

Gambar 4. Histogram Hubungan antara Kekuatan Gel dengan Konsentrasi PEG

Berdasarkan Gambar 4 di atas dapat terlihat bahwa hasil ekstraksi agarosa dengan nilai kekuatan gel paling tinggi sebesar $379,04 \mathrm{~g} / \mathrm{cm}^{2}$ pada perlakuan PEG $20 \%$, dan nilai kekuatan gel paling rendah sebesar $114,08 \mathrm{~g} / \mathrm{cm}^{2}$ pada perlakuan PEG $15 \%$, sebagai pembanding digunakan standar agar-agar komersial (Swallow) dengan kekuatan gel agar-agar komersial sebesar $1635,12 \mathrm{~g} / \mathrm{cm}^{2}$.

Pengukuran kekuatan gel hasil ekstraksi dibandingkan dengan agar-agar komersil karena pada dasarnya agar-agar komersil mengandung agarosa. Kekuatan gel hasil ekstraksi masih jauh lebih rendah dibandingkan dengan kekuatan gel agar-agar komersil. Hal ini kemungkinan disebabkan karena di dalam rendemen yang dihasilkan masih banyak terkandung agaropektin. Menurut Winarno, (1990) kekuatan gel agaragar sangat tergantung pada perbandingan agarosa terhadap agaropektin. Hal yang mempengaruhi kekuatan gel juga adalah adanya kandungan ester sulfat (Armeidy, 1992). Perbedaan hasil kekuatan gel ini juga diduga disebabkan oleh perbedaan kandungan galaktosa dan sulfat yang terdapat di dalam sampel. Semakin tinggi kandungan sulfat pada agarosa maka kekuatan gelnya akan rendah (Rizqi, 2011).

\section{2) Kadar Sulfat}

Salah satu ciri agarosa adalah netral, tidak mengandung sulfat. Berdasarkan hasil penelitian kadar sulfat yang terkandung pada hasil ekstraksi agarosa berkisar antara 1,33$1,85 \%$ sedangkan kadar sulfat pada Rumput Laut kering sebesar 3,67\% dan kadar sulfat pada standar agar-agar komersil sebesar
0,85\%. Adapun hubungan kadar sulfat dengan konsentrasi PEG hasil penelitian dapat dilihat pada Gambar 5.

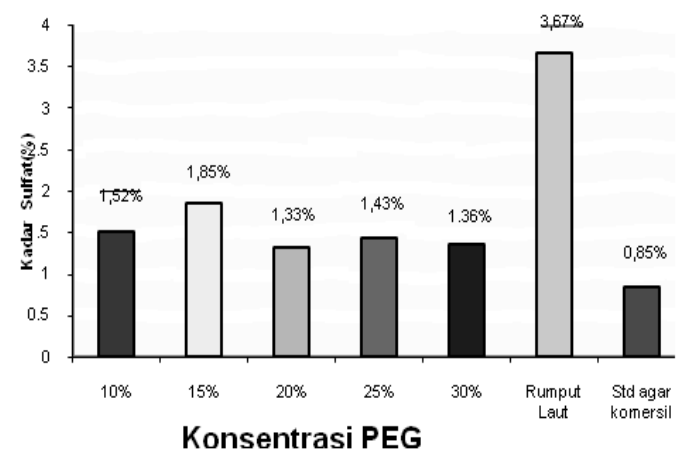

Gambar 5. Histogram Hubungan antara Kadar Sulfat dengan Konsentrasi PEG

Dari Gambar 5 di atas terlihat bahwa kadar sulfat yang paling rendah yaitu 1,33\% terdapat pada perlakuan konsentrasi PEG $20 \%$ sedangkan kadar sulfat yang paling tinggi yaitu sebesar $1,85 \%$ pada perlakuan konsntrasi PEG 15\%. Kadar sulfat hasil ekstraksi agarosa lebih rendah dari kadar sulfat rumput laut kering, hal ini berarti penambahan PEG berpengaruh terhadap penurunan kandungan sulfat yang terdapat pada rumput laut kering. Namun jika dibandingkan dengan standar agar-agar komersil, kadar sulfat hasil ekstraksi masih tinggi. Hal ini diduga masih terdapat kandungan agaropektin pada hasil ekstraksi yang belum terpisah, karena pada saat penyaringan larutan setelah ditambahkannya PEG, larutan masih dalam keadaan panas sehingga semua larutan lolos dari saringan dan diduga agaropektin yang masih mengandung sulfat ikut terbawa. Akan tetapi terdapat hubungan terbalik antara kandungan sulfat dengan kekuatan gel yang dihasilkan, adanya sulfat akan membentuk kekakuan pada rantai polimer sehingga menghambat terbentuknya pilinan ganda (Fitri, 1992). Semakin tinggi kadar sulfat maka kekuatan gel yang dihasilkan akan semakin kecil. Karena ester sulfat pada atom karbon ke 6 dari L-galaktosa (C6) menyebabkan rantai polimer membentuk tekukan yang dapat menghambat proses pembentukan gel (Glicksman, 1983). 
Gel yang kuat merupakan salah satu kriteria yang penting sehubungan dengan penggunaan agarosa dalam bidang bioteknologi. Chapman-chapman dalam Fitri tahun (1992), mengatakan bahwa kandungan sulfat di dalam agarosa adalah 0.03-0.04\%, sedangkan menurut Guiseley dan Renn (1975), agarosa dengan kadar sulfat 0,7\% masih dapat diterima tetapi agarosa yang sering terdapat dipasaran memiliki kadar sulfat sekitar 0.1-0.35\% (Subaryono, 2003). Sehingga kadar sulfat agarosa hasil ekstraksi masih belum memenuhi standar dipasaran.

\section{3) Kandungan Galaktosa}

Karbohidrat yang terkandung di dalam agar merupakan campuran polisakarida yang terdiri dari dua fraksi yaitu agarosa dan agaropektin. Galaktosa merupakan monomer terbesar yang terdapat di dalam agarosa. Berdasarkan hasil penelitian pada ekstrak agarosa, kandungan galaktosa berkisar antara $13.40 \%$ - $17.39 \%$. Adapun hubungan kandungan antara galaktosa dengan perlakuan konsentrasi PEG hasil penelitian ini dapat dilihat pada Gambar 6.

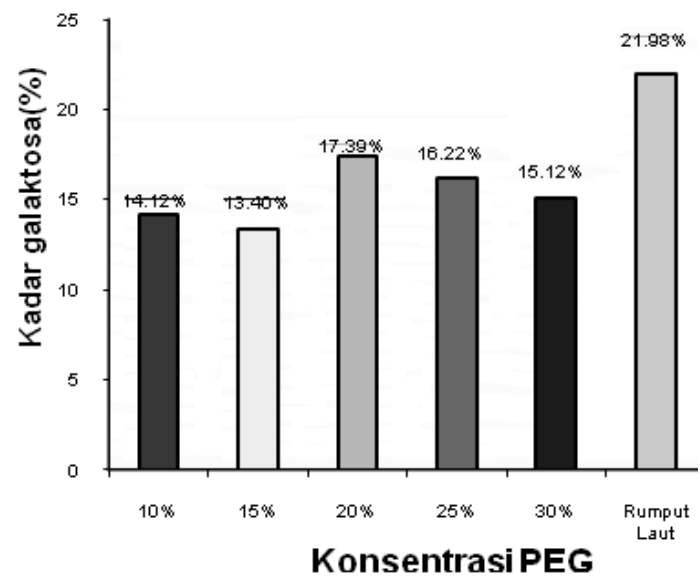

Gambar 6. Histogram Hubungan antara Kadar Galaktosa dengan Konsentrasi PEG

Dari Gambar 6 dapat dilihat bahwa kandungan karbohidrat sebagai galaktosa yang terkandung dalam rumput laut hasil ekstrak yang paling rendah yaitu $13.40 \%$ pada perlakuan konsentrasi PEG $15 \%$ dan kandungan galaktosa paling tinggi yaitu $17.39 \%$ pada perlakuan konsntrasi PEG $20 \%$, sementara kandungan karbohidrat sebagai galaktosa pada Rumput Laut kering sebesar $21.98 \%$ dan kandungan karbohidrat sebagai galaktosa pada standar agar-agar komersil sebesar $19.68 \%$. Pada penambahan PEG dari 10\% hingga 20\% terjadi kenaikan kandungan galaktosa, sedangkan kandungan galaktosa menurun kembali pada perlakuan PEG 25\% dan 30\%, titik optimum terjadi pada perlakuan PEG $20 \%$ yaitu sebesar $18,11 \%$. Kandungan galaktosa berbanding lurus terhadap kekuatan gel. Kadar galaktosa yang tinggi dan kadar sulfat yang rendah memiliki kekuatan gel yang tinggi hal ini berariti kandungan agarosa lebih banyak.

Menurut Chapman dan Chapman dalam Fitri (1992), kandungan galaktosa pada agarosa berkisar antara 31.90\% - 51.00\%. Kandungan galaktosa rumput laut menurut FAO (1972) adalah 83.5\% sedangkan yang disyaratkan SNI adalah lebih dari 30\% (Angka \& Suhartono 2000). Jika dibandingkan dengan kadar galaktosa standar agar-agar komersil $(19,68 \%)$, maka kadar galaktosa hasil ekstraksi masih sedikit lebih rendah. Menurut Armeidy (1992), penurunan kadar galaktosa yang terjadi disebabkan karena terdegradasinya galaktosa. Degradasi ini terjadi karena terhidrolisisnya agarosa menjadi disakarida yang berantai pendek. Tinggi rendahnya kadar galaktosa dipengaruhi oleh kandungan agarosa dan agaropektin. Karbohidrat merupakan senyawa organik yang terdiri dari serat kasar dan bahan bebas tanpa nitrogen (nitrogen free extract).

\section{e. Proksimat Agarosa Gracilaria sp. 1) Kadar Air}

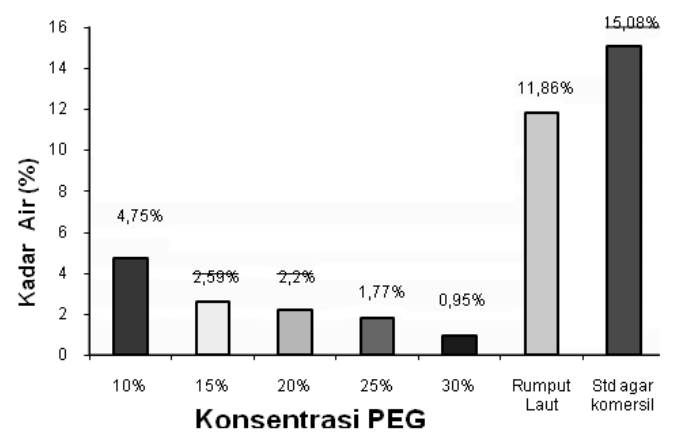

Gambar 7. Histogram Hubungan antara Kadar Air dengan Konsentrasi PEG 
Kadar air adalah kandungan air bahan yang dinyatakan berdasarkan perbandingan antara berat basah dan berat kering. Berdasarkan hasil penelitian, kadar air yang diperoleh berkisar antara $0.92-4,75 \%$. Adapun hubungan kadar air terhadap konsentrasi PEG dapat dilihat pada Gambar 7.

Hasil penelitian terlihat semakin tinggi konsentrasi PEG maka kadar airnya semakin rendah, hal ini karena secara kimiawi, PEG merupakan sekelompok polimer sintetik yang larut air dan memiliki gugus hidroksil primer pada ujung rantai polieter yang mengandung oksietilen $\left(-\mathrm{CH}_{2}-\mathrm{CH}_{2}-\mathrm{O}-\right)$ sehingga dapat mengikat air dalam sampel. Semakin banyak PEG yang ditambahkan maka air yang terkandung pada ekstrak agarosa semakin berkurang karena terikat oleh PEG. Kadar air yang disyaratkan oleh SII untuk Rumput Laut kering adalah 13,2\% (Soegiarto \& Sulistyo, 1985), sedangkan kadar air maksimal yang disyaratkan oleh SNI untuk agar-agar berkisar antara $15-24 \%$ (Angka \& Suhartono, 2000). Menurut Subaryono, et al. (2003) kadar air agar-agar adalah kurang dari 14\%. Rendahnya kadar air yang dihasilkan dalam penelitian karena pada saat pengeringan menjadi serbuk agarosa, lembaran agarosa sebelum diblender di hangatkan $2-3$ kali di dalam oven pada suhu $50-60{ }^{\circ} \mathrm{C}$ sehingga pada penentuan kadar air diperoleh kadar air yang rendah.

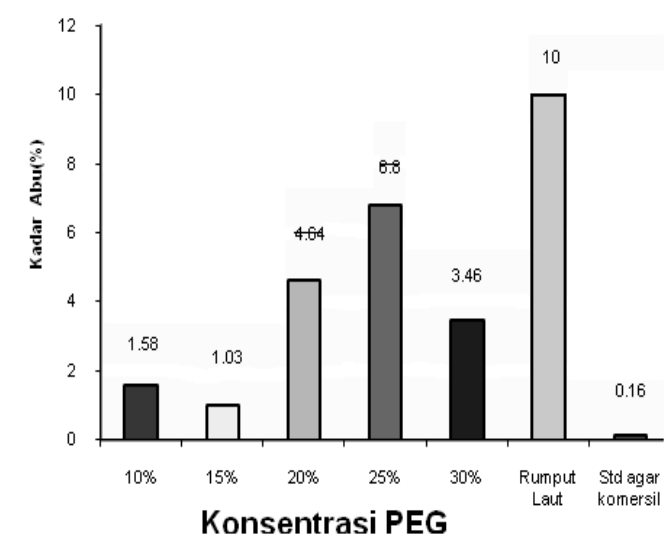

Gambar 8. Histogram Hubungan Kadar Abu dengan Konsentrasi PEG

\section{2) Kadar Abu}

Kadar abu dalam bahan pangan ditetapkan dengan menimbang sisa mineral sebagai hasil pembakaran bahan organik. Kadar abu yang dihasilkan pada penelitian ini berkisar antara $1.03-6.80 \%$. Kadar abu paling rendah yaitu $1.03 \%$ diperoleh pada perlakuan konsentrasi PEG 15\% dan kadar abu yang paling tinggi yaitu $6.8 \%$ diperoleh pada konsentrasi PEG 25\%, Sementara kadar abu yang disyaratkan oleh SII adalah sebesar 4\%. Hubungan antara kadar abu dengan konsentrasi PEG dapat dilihat pada Gambar 8.

Berdasarkan Gambar 8 kadar abu yang diperoleh pada konsentrasi PEG 10\% $(1,58 \%)$ dan PEG $15 \%(1,03 \%)$ memenuhi standar SII (maksimum 4\%), pada perlakuan konsentrasi PEG di atas 15\% kadar abu tidak memenuhi syarat SII, hal ini kemungkinan disebabkan karena kandungan anorganik yang terdapat pada sampel berbeda-beda. Abu atau mineral merupakan komponen yang tidak mudah menguap pada waktu pembakaran dan pemijaran senyawa organik atau bahan alam (Soebito, tahun 1988). Abu yang terdapat dalam tepung agar-agar berasal dari garam atau mineral yang terdapat pada rumput laut yang digunakan, sebagian besar terdiri dari Natrium dan Kalsium. Tinggi rendahnya kadar abu pada rumput laut disebabkan karena tinggi rendahnya kandungan mineral dalam Rumput Laut tersebut. Kurang bersihnya pencucian dan perbedaan pucuk dengan tangkai pada sampel Rumput Laut dapat juga menyebabkan tinggi rendahnya kadar abu pada tepung agar-agar hasil ekstraksi.

\section{3) Protein}

Komponen protein dalam agar-agar terdapat dalam jumlah yang kecil. Berdasarkan hasil penelitian kadar protein berkisar antara $0,78 \%-1,05 \%$, sedangkan kadar protein untuk sampel rumput laut kering sebesar $1,22 \%$ dan standar agar-agar komersil sebesar $0,12 \%$. Hasil kadar protein pada sampel hasil ekstrak dapat dilihat pada Gambar 9. 


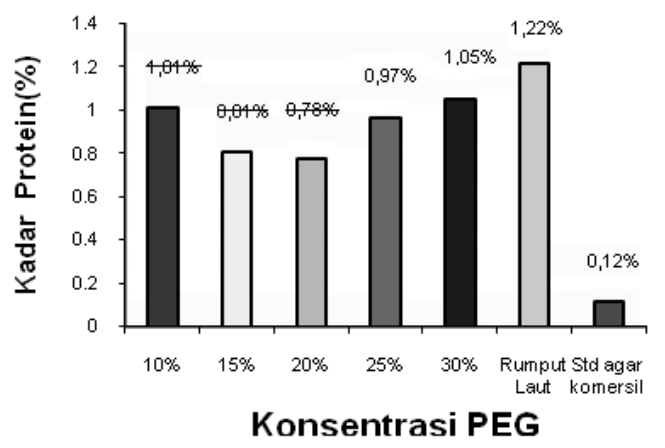

Gambar 9. Histogram hubungan antara kadar protein dengan konsentrasi PEG

Pada Gambar 9 terlihat bahwa kandungan protein pada rumput laut kering memenuhi standar yang disyaratkan oleh FAO yaitu sebesar 1,3\% sedangkan untuk kadar protein agar-agar hasil ekstrak lebih besar $(0,76 \%-1,05 \%)$ dari kadar protein agar-agar komersil sebesar 0,2\%.

Protein merupakan zat makanan yang penting bagi tubuh karena sebagai sumber energi, zat pembangun, dan zat pengatur (Winarno, 1996).

\section{4) Lemak}

Komponen lemak pada agar terdapat dalam jumlah yang kecil. Berdasarkan pengukuruan kandungan lemak yang terdapat pada ekstrak agarosa berkisar antara $1.23 \%$ - $3.53 \%$, Nilai kadar lemak pada ekstrak agarosa dapat dilihat pada Gambar 10.

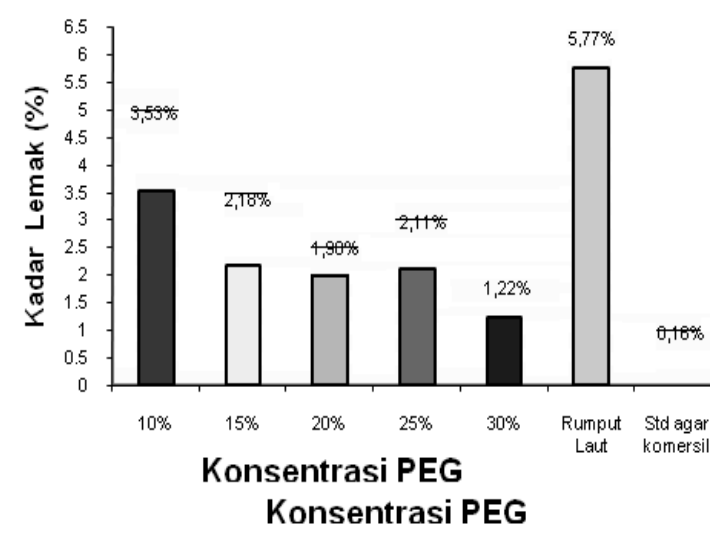

Gambar 10. Histogram Hubungan antara Kadar Lemak dan Konsentrasi PEG
Berdasarkan Gambar 10 di atas, kadar lemak paling tinggi terdapat pada perlakuan konsentrasi PEG 10\% sebesar 3,53\% dan kadar lemak paling rendah terdapat pada konsentrasi PEG 30\% sebesar 1,22\%. Kadar lemak yang disyaratkan oleh FAO (1972) untuk rumput laut kering sebesar $\leq 1.2 \%$ (Fitri, 1992) dan kadar lemak untuk agaragar sebesar 0.1\% (Susanto, 1978). Pada Gambar 10 terlihat bahwa kandungan lemak yang terdapat pada hasil ekstraksi masih tinggi dibandingkan dengan standar. Kadar lemak yang dihasilkan baik dari rumput laut kering maupu agar-agar hasil ekstraksi tidak memenuhi standar. Banyak faktor yang mempengaruhi dalam analisis kadar lemak salah satu diantaranya, alat-alat yang digunakan untuk analisis masih mengandung lemak. Lemak sukar larut dalam air sehingga sisa lemak yang terdapat pada alat ikut terlarut dalam larutan organik yang digunakan. Lemak merupakan salah satu unsur yang penting untuk menjaga kesehatan tubuh manusia. Lemak di dalam tubuh juga sebagai cadangan makanan.

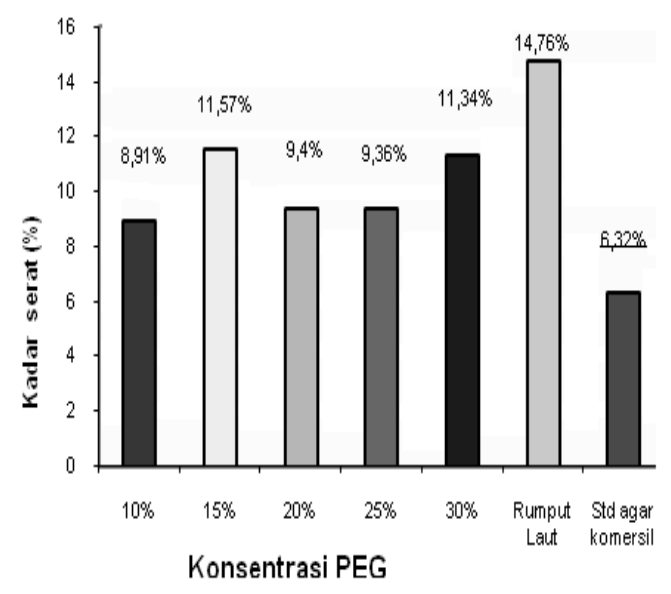

Gambar 11. Histogram Hubungan Kadar
Sserat Kasar dengan
Konsentrasi PEG

\section{5) Serat Kasar}

Serat banyak terdapat pada dinding sel rumput laut. Secara kimia dinding sel tersebut terdiri dari beberapa jenis karbohidrat salah satunya yaitu selulosa (Winarno, 1996). Berdasarkan hasil penelitian kandungan kadar serat kasar pada agar-agar hasil ekstraksi berkisar antara 
9,36\% - 11,57\% sedangkan kadar serat kasar pada rumput laut kering sebesar $14,76 \%$. Kadar serat kasar pada tepung agar-agar hasil ekstrak dapat dilihat pada Gambar 11.

Kandungan serat kasar yang disyaratkan pada rumput laut kering menurut FAO (1972) sebesar 2.7\% (Fitri, 1992), dan kadar serat kasar untuk agar-agar menurut Susanto (1978) sebesar 0.1\%. Kandungan serat kasar pada rumput laut kering maupun tepung agar-agar yang dihasilkan lebih besar dari yang disyaratkan. Hal ini dikarenakan kandungan rumput laut Gracilaria sp kaya akan serat sebagai bahan utama dalam pembuatan agar.

Serat makanan adalah bahan pangan yang berasal dari tanaman, yang tahan terhadap pemecahan oleh enzim dalam saluran pencernaan, dan tidak dapat diabsorpsi. Zat ini terdiri dari selulosa dengan sedikit lignin dan sebagian kecil hemiselulosa (Apriyanto, 1986). Kandungan karbohidrat dalam bentuk serat kasar dalam jumlah tertentu diperlukan untuk membentuk gumpalan kotoran sehingga memudahkan dalam pengeluaran feses dari dalam usus. Karbohidrat pada rumput laut tidak dapat diasimilasi untuk menghasilkan energi sehingga baik untuk diet. Pada dasarnya kandungan serat yang terdapat dalam rumput laut adalah yang paling besar dan merupakan kandungan paling utama. Sehingga berdasarkan penelitian, kandungan serat kasar yang terdapat dalam Rumput Laut Gracilaria $s p$ cukup besar jika dibandingkan dengan standar agar-agar komersil. Serat ini bersifat mengenyangkan dan memperlancar proses metabolisme tubuh sehingga sangat baik dikonsumsi penderita obesitas. Serat tidak dapat diserap oleh tubuh sehingga banyak digunakan sebagai makanan untuk diet.

\section{KESIMPULAN}

Berdasarkan hasil penelitian, isolasi agarosa perlakuan konsentrasi dengan Poliethylen Glikol (PEG) 6000 pada Rumput Laut Gracilaria $s p$ di peroleh rendemen paling tinggi terdapat pada perlakuan PEG $30 \%$ yaitu sebesar $61,27 \%$ akan tetapi untuk kualitas agarosa yang paling baik terdapat pada perlakuan konsentrasi PEG 20\% karena diperoleh Kekuatan Gel paling tinggi yaitu sebesar $379,04 \mathrm{~g} / \mathrm{cm}^{2}$, kadar sulfat yang paling rendah yaitu sebesar 1,33\% dan kadar galaktosa sebesar $17,39 \%$ Sehingga dapat disimpulkan bahwa perlakuan PEG $20 \%$ adalah perlakuan yang paling optimum untuk mengisolasi agarosa dari rumput laut Gracilaria sp.

\section{SARAN}

Agar penelitian ini lebih sempurna, perlu penelitian lebih lanjut untuk mengisolasi agarosa murni yaitu, pengaruh suhu terhadap perendaman praperlakuan, pengaruh ekstraksi bertingkat (ekstraksi tidak hanya dilakukan 1 kali pemanasan) dan penyaringan setelah penambahan PEG dilakukan pada suhu hangat $\left( \pm 30-40{ }^{\circ} \mathrm{C}\right)$ sehingga agarosa yang dihasilkan lebih banyak dan lebih murni.

\section{DAFTAR PUSTAKA}

Anggadireja, J.T, Zatnika A., Purwoto H., Istini S., 2006. Rumput Laut. Penebar Swadaya, Jakarta.

Angka, SL dan Suhartono. 2000. Bioteknologi Hasil Laut. Pusat Kajian Sumberdaya Pesisir laut IPB. Bogor.

AOAC. 1995. Official Methods of Aanalysis of the Assosiation of Official Analytical Chemistry. 16 th ed A.O.A.C., Inc. Arlington. Virginia

AOAC. 2000. Official Methods of Aanalysis of the Assosiation of Official Analytical Chemistry. Ed ke-17. Sydney William, editor. Arlington, Virginia: AOAC.

Apriyanto A, Fardiaz D, S. Budiyanto dan N. L. Puspitasari. 1986. Penuntun Analisa pangan. Jurusan Teknologi Pangan dan Gizi IPB. Bogor

Armeidy. 1992. Pengaruh Konsentrasi Asam dan Lama Perendaman Optimal 
Terhadap Rendemen dan Mutu Agar Gracilaria verrucosa. Skripsi. Fakultas Teknologi Pertanian. IPB, Bogor.

Asmarita. 2000. Pengaruh Ukuran Bahan Baku Rumput Laut dan Jenis Kain Mutu Saring Terhadap Rendemen dan Tepung Agar-agar. Skripsi. Fakultas Perikanan dan Ilmu Kelautan. IPB, Bogor.

Atmadja WS, Sulistijo. 1983. Beberapa Aspek Vegetasi dan Habitat Tumbuhan Laut Bentik di Pulau-pulau Seribu. Pusat Penelitian Pengembangan Oseanografi LIPI. Jakarta

Chapman, V.J., and Chapman, C.J. 1980. Seaweed and Their Uses, 3rd ad., pp. 148-193. Chapman and Hall Ltd. London.

Delly, S. 2007. Pemanfaatan Rumput Laut dalam pembuatan Permen Jelly. Skripsi. Fakultas Perikanan dan Ilmu Kelautan IPB. Bogor

Distiantina, S., Sediawan, W.B., dan Kulyono, P. 2001. Pengaruh Perendaman Rumput Laut dengan HCL terhadap Ekstraksi Agar-agar Menggunakan Pelarut Air. Prosiding Seminar Nasional Kejuangan 2001.

Fessenden R.J. dan J.S. Fessenden 1986. Kimia Organik Edisi Ketiga. Erlangga, Jakarta.

Fitri, E. 1992. Isolasi Agarosa Dengan Metode Polyethylene Glycol (PEG METHOD) dan Agar-agar Gracilaria sp.. Skripsi. Fakultas Teknologi Pertanian. IPB, Bogor.

Fransiska, Dina dan Murdinah. Prospek Produksi Agarosa dan Agar Mikrobiologi Di Indonesia. Jurnal. Squalen Vol. 2 No. 2, Desember 2007.
Glicksman, M. 1983. Food Hydrocolloid. Volume ke-2. CRC. Boca Raton., Florida.

Indriani, H. dan E. Sumiarsih. 2003. Budidaya Pengolahan dan Pemasaran Rumput Laut. Penebar Swadaya, Jakarta.

Istini, S. 1986. Manfaat dan Pengolahan Rumput Laut. Majalah BPPT: 1-12, Jakarta.

Kadi, A. 2004. Potensi Rumput Laut Di Beberapa Perairan Pantai Indonesia. Oseana, Vol. XXIX, No. 4, Tahun $2004: 25-36$.

Lindawati. 2010. Pengaruh pH Terhadap Efektifitas Natrium Benzoat Dalam Minuman Sari Kelapa Berdasarkan Uji Mikrobiologi. Skripsi. Fakultas Matematika dan Ilmu Pengetahuan Alam. UNB, Bogor.

Rachmat, R., Sulistijo dan A.B. Susanto. 2004. Ekstraksi Agarose dari Agarofit Gracillaria verrucosa, hlm. 138-145. Prosiding Seminar Nasional Rumput Laut dan Mini Symposium Mikroalgae 23-25 Oktober 2002. Ikatan Fikologi Indonesia, Jakarta.

Rasyid, A. 2004. Berbagai Manfaat Alga. Jurnal Kelautan. Puslitbang Oseanologi LIPI hlm. 9-15. Vol 3., Jakarta

Rasyid, A., R. Rachmat, dan T. Murniasih. 1999. Karakteristik Polisakarida Agar dari Gracilaria sp. dan Gelidium sp. Jurnal Kelautan. Puslitbang Oseanologi-LIPI halaman 57-62, Jakarta.

Rizqi, N.A .2011. Isolasi Agarosa Rumput Laut Gracilaria sp. dan Eucheuma sp. Skripsi. Fakultas Matematika dan Ilmu Pengetahuan Alam. UNB, Bogor.

Salamah dan Ella. 2005. Kualitas Agarosa Hasil Isolasi dari Rhodymenia ciliate 
Menggunakan DEAE-Selulosa. Buletin Teknologi Hasil Perikanan Vol. VIII No. 1 tahun 2005.

Satriyana. 2002. Pengaruh Penambahan Iota Karaginan Pada Proses Ekstraksi Agarosa dari Rumput Laut Gracilaria chilensis Dengan Metode Cetyl Pyridinium Chloride. Skripsi. Fakultas Perikanan dan Ilmu Kelautan. IPB, Bogor.

Soegianto, S., W.S. Atmadja \& H. Mubarak. 1978. Rumput Laut (Algae): Manfaat, Potensi, dan Usaha Budidaya. Jurnal Kelautan. Lembaga Oseanologi Nasional-LIPI. Jakarta.

Soerawidjaja T.H. 2005. Alga Sebagai Biotarget Industri. Jurnal Saint dan Teknologi BPPT.
Sudjana, 1982. Desain dan Analisis Eksperimen. Tarsito. Bandung Tim Elsspat Pengawetan Kayu dan Bambu. Cetakan Pertama. Dinamika Media. Jakarta

Subaryono B.S.B. 2003. Pengaruh Penambahan Iota Karaginan pada Ekstraksi Agarosa dari Agar-agar Menggunakan Cetyl Piridium Klorida. Jurnal Penelitian Perikanan Indonesia Vol. 9. Nomor 5: 1-9.

Susanto, M, P. Lappas dan S. Endang. 1978. Penelitian Agar-agar Pada Bermacam-macam Jenis Sango-sango (Rumput Laut) di Sepanjang Pantai Makasar. Balai Penelitian Kimia Ujung Pandang.

Winarno, F.G. 1996. Teknologi Pengolahan Rumput Laut. Pustaka Sinar Harapan. Jakarta. 